さらに異音の点が未解決のようである。しか し空压の利点は、速度・カ・重量の点ではす るので、今後の研究発展を期待したい。次に 兵庫リハセンタの中島氏らの筋電制御システ ムにおける切断手技の影響に関する研究仕、 てのセッション唯一のMからの発表である。 今後筋電制御電動義手が実用化されて行くこ とを見越して、どの上うに切断した場合に最 子良好な筋電情報が得られるかを $\bar{\tau}-\mathrm{S}$ 関係 を示標として見ている。結論的には、骨の断 端を適当な緊張下の筋肉で被覆する方法がそ うでない、いわゆるギロチン式切断上りるよ らとのととである。義手受入れ者側からのと の上らな研究がもっとなされるべをととを、 この会では特に感じたるのである。ついで徳 島大榊原氏らの筋電の周波数情報による多機 能前踠義手の制御は前腕筋群の協調動作に上 る複合筋電のパターン識別によって多自由度 制御を試みるもので、簡単な学習により識別精度は 高くなり $100 \%$ 近い識別率が得られたとい ら。前腕義手以上飞多自由度制御を要求され る上腕義手、肩離断用義手にこの方式が実用 される可能性を私に是非期待したい。つぎの 早大加藤研からの電油式多自由度前腕義手

(ワセダハンド9H3) は従来からの眯案で あった油压式アクチュエータを前腕義手の実 用化に主で持って行ったるので、やはりマイ クロコンを用いての筋電に上り制御する方式 をとっている。軽量化・リークの問題なぼが 解決されれば、実用義手の有力な武器の1つ として大いに期待されょら。つれ゙の德島大木 下氏らの電動義手の柔加協調動作制御の研 究では、肩離断者用の多自由度義手を想定し て、この制御を有・頭・眼の動をでなるべく 生理学的に行おらとするるのであり、実験に は正常者を用いている。私る加って先天性上 肢欠損垐の 3 自由度型電動義手に肩峰の動を で 2 自由度、下顎の動きで 1 自由度を制御す る方式をとったが、かなりらまい制御が出来 た。今後多自由度義手制御方式にはいろいろ
なのが出て来るであるらがやはり動かすの は人間であるからには、何とか生理学的に無 理のない範囲内でおさめたい。頭や目の動を を用いるととには実際上の限界はあるうが、 一層の研究を期待したい。最後の演題すやは り德島大長岡氏らのもので装具に上って逆に 正常人上肢の動作を解析し、義手の複合動作 の制御に用いようとするもので、一つの現実 解と思う。

以上簡単に、私の理解出来た範囲内での私 見を述べたが、義手の研究であるからには、 途中のブロセスでどうであれ、最終的には切 断者がそれをつけ、役に立つかどうかにょり 評価されるべきすのである。Mの立場から云え ば、研究題目は義手であっても、患者に装着 が出来なければマシンハンドやロボットに応 用出来るではないかといら逃げは絶対に出来 ない。この点での甘さがあると、研究のため の研究飞陌る危険性が大いにあると痛感し ている。中途半端な段階での臨床応用も避け ね壮ならないが臨床応用がお題目のみである 危険にる留意しなくてはならない。今回での 発表に、るっともっと $\mathrm{M}$ 側の一人として大らに反省もしたのが最大 の印象であった。

3. 夜話花房秀郎(京大) 魚の尾ビレの運動その応用いろいろ シンポジム第一日の夜話は、新幹線の午 前中運転休止の余波で午後 8 時半開始となり、 一層夜話らしい雾囲気となった。話題は魚の 尾びれの運動、その応用いろいろということ で、移動機構の原理を動物の運動に立ちもどつ て探り、てれを機構的に害現して人間の使う 道具瓜用しょうといらすのである。

まず魚の推進原理をポンプと対比させなが ら、揚力形、抗力形、遠心力形汇分類し、そ れぞれが人力ボートや水泳具として利用でを るととを示された。さらに水中推進の翼 の摇動が陸上推進では車輪の摇動飞類似 のものであるととに着目し、摇動車 
輪による推進装置の開発について話された。 その原理はキャスターの上うな摇動車輪を強 制的に摇動させるととにより、あおりに相当 する効果を生し、てれが推進力にるるのであ る。との原理の応用として二輪尻振スタート、 三輪ワンダースクート、身障者用ワンダーサ イクルについて話されたが、これらはいずれ る実用化された白のであり、特に身障者用ワ ンダーサイクルは、前二輪が独立のハンドル を有し、その首振り角度により速度制御のみ ならず、前後進すでをるすのである。

摇動車輪はさらに直線運動から回転運動へ の運動変換装置に応用でさるととが示された。 これには円板駆動型と円筒駆動型があり、そ れぞれ円板面また㤌円筒内面にキャスタを接 触させながら直線運動させると、キャスタの 首振りによって推進力を生じ、円板まをは円 筒が回転する。この機構はクランクのような 上死点、下死点がないのて起動が容易なとと が特徵であり、足踏みろくろなどの応用例。 示された。

模型を使いながらの興味深い話に㯖衆はし 壮し魅了されたが、技術の開発における連想 の重要性、生活を豊かにするための道具の見 直しを力説されたのが印象的であった。

\section{4. 感覚清水嘉重郎（機械技研）}

ハイオメカニズム学会のシンポシウム会場 は例年すばらしい環境の中で行われているて とはすでに定評となっているが、今回は愛知 県労働者研修センターで開催された。ここの 設備・環境もまたシボシウム会場として申 し分なく、とのような立派な会場の選定と準 備に当られた幹事の方々、お世話下さった方 々にはずお礼を申しのべたい。

さて、第 2 日目午前・前半のセッションは 皮虐感覚に関する研究発表を中心に進如られ

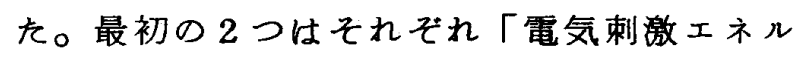
キーーと皮膚感覚」(機械技研)お上び「皮唐 電気刺激に上る情報伝達の基礎的特性」（都
補装具研)て、これらはいずれる皮屚の電気 刺激に上る情報伝達の問題でその基礎的な研 究である。それぞれは定電流刺激および定電 压刺激と刺激方法が異をっており、またアブ ロ一チのし方る若干相異していた。しかし両 者共上腕皮庙人の電気刺敫であり、刺激強度 と加えた電気刺激のエネルギーとの関係、ダ イナミックレンジの問題や、刺激の強度と周 波数次元に関する了度可知差異之最大伝達情 報量の問題など、中心課題については互いに 共通するすのが取上げられており、得られた 結果につらて。共通点が少くない。恐らく相 互の情報交換が日頃上く行われていたためと 思う。しかしテーマは同様ですそれぞれに個 性が認められて研究の内容に幅と深みを与え るととになり興味梁いるのとなった。なお最 大伝達情報量が従来知られている機械的振動 刺激によるそれと在とんど変りないとすれば、 小型・軽量化の期待でをる電気的刺激の方が 有利であろら。今後の研究の進展が期待され る。

次に「多自由度義手の制御信号と位置フィ ードハック」(早大理工)につんては、義手 の制御信号および義手の位置感覚のフィード バック信号を腹部皮庯への電気刺激によって 行わせようとするすのである。義手操作のた めの制御信号を本報告のよう飞箭電と腹部人 の電気刺激パターンとの組合わせによって得 ようとする試み、並びに義手の位置感覚を視 覚フィードハックル上らす腹部への電気刺激 ハターンによって得よらとする試みは、特に 上胞・肩義手飞関して操作の多種・多様性を 可能にする一方法として大変興味梁い。今回 はヒトの腹部電気刺激に対する応答特性とい ら面からの報告が中心ですっだ、実際の義 手を装着した場合の諸動作との関連、筋電と のやりとりの問題、学習訓練の問題、発汗そ の他の諸条件への対策をど今後に残された問 題加多い。

「乳癌触診の定量化に関する基䅍研究」 